\title{
STABILISASI TANAH DASAR DENGAN BAHAN ADITIF AKIBAT BEBAN SIKLIK JALAN REL KERETA CEPAT JAKARTA - BANDUNG
}

\section{SOIL STABILISATION FOR SUBGRADE WITH ADDITIVE MATERIAL DUE TO CYCLIC LOAD FAST RAILWAY JAKARTA-BANDUNG}

\author{
Widy Cahyono ${ }^{1}$, Ahmad Rifa' ${ }^{2}$ \\ ${ }^{1,2}$ Program Studi Teknik Sipil-Fakultas Teknik-Universitas Gadjah Mada Yogyakarta \\ Jl. Grafika No. 2 Kampus UGM Yogyakarta 55281 \\ email: widy.cahyono@mail.ugm.ac.id ; rifai@ugm.ac.id
}

\begin{abstract}
Indonesian is a developing country, as a developing country Indonesian Government countinou to build infrastructure. Which one of them is the build of Jakarta-Bandung high-speed railroad. Many technical studies need to be done of the implementation. One of thing is Geotechnical field is the provision of stocpiles for subgrade. The soil used for research is taken from wallini Village, Cikalong Wetan, West Bandung. This research was conducted to obtain of the required subgrade soil. Soil modification is carried out by mixing between soil dan variation of cements and soil, additives and variation of cements. The variation of cements is mixture 1\%, 2\% and 3\%, additives mixture is 0,15\% from Maximum Dry Density (MDD). The stages of testing of the physical properties of soil and mechanical properties of soil. Test was carried out to obtain submerged CBR Values and Free Compressive Strength (qu) values. That parameter was then entered into PLAXIS 8.6 program. The original soil is Silt with submerged CBR values of $8.17 \%$. Numerical simulation analysis with train axle load is 170 $k N$, displacement that occurred was equal to $-0.065 \mathrm{~mm}$ for static load and displacement for dynamic load equal 0.015 x 10-3, for one time cyclic load train. Displacement for dynamic load and earthquake load 0.4g, equal to 0,576 x 10-3, it happens at the subgrade midpoint between the two train axle loads. Stabilization of subgrade with additives 0,15\% MDD and 1\% variation, of cement and subgrade thickness 0,35 $\mathrm{m}$ is able to support axle load fast train.
\end{abstract}

Keywords: Soil modification; Subgrade; Soil Bearing Capacity

\begin{abstract}
Abstrak
Sebagai Negara yang masih terus membangun Pemerintah Indonesia terus melakukan pembangunan infrastruktur, salah satunya adalah pembangunan jalur kereta cepat JakartaBandung. Banyak kajian teknis yang perlu dilakukan terhadap pelaksanaannya. Salah satu yang perlu dikaji dalam bidang geoteknik yaitu penyediaan timbunan untuk subgrade. Tanah yang digunakan sebagai penelitian yaitu tanah yang diambil dari desa Walini, Cikalong Wetan, Bandung Barat. Penelitian ini dilakukan untuk mendapatkan nilai daya dukung tanah subgrade yang dipersyaratkan. Modifikasi tanah dilakukan dengan pencampuran antara tanah dan variasi semen, dan tanah, zat aditif dan variasi semen. Zat aditif yang digunakan 0,15\% MDD, dan variasi semen yang digunakan adalah campuran $1 \%, 2 \%$ dan $3 \%$. Pengujian dilakukan melalui tahapan pengujian sifat fisik tanah, dan sifat mekanis tanah. Pengujian dilakukan untuk mendapatkan nilai CBR terendam, dan nilai kuat tekan bebas (qu).Parameter tersebut digunakan sebagai input data pada program PLAXIS 8.6. Tanah timbunan yang dipakai merupakan jenis lanau, dengan nilai CBR terendam sebesar 8,17 \%. Analisis simulasi numeris dengan axle load kereta sebesar $170 \mathrm{kN}$ didapat penurunan tanah yang terjadi sebesar $-0,065$ mm untuk beban statis dan 0,015 x 10-3 mm untuk 1 kali beban siklik kereta. Pada beban dinamis dan beban gempa sebesar 0,4g didapat penurunan sebesar 0,576 x 10-3 mm. Analisis pada penurunan tersebut dilakukan pada titik tengah subgrade diantara kedua beban gandar kereta. Stabilisasi subgrade dengan zat aditif 0,15\% MDD dan dan campuran semen $1 \%$ dengan ketebalan subgrade $0,35 \mathrm{~m}$, mampu menahan axle load kereta cepat.
\end{abstract}

Kata kunci: Modifikasi tanah; Subgrade; Daya dukung tanah 


\section{PENDAHULUAN}

Demi meningkatkan pelayanan transportasi maka pemerintah giat melakukan infrasrtuktur, salah satu dari pembangunan infrastruktur yaitu pembangunan kereta cepat Jakarta-Bandung. Salah satu yang perlu dikaji adalah penyediaan tanah timbunan dan juga subgrade. Seberapa besar daya dukung tanah timbunan tersebut mampu mendukung gaya gaya yang bekerja diatasnya. Rute dari jalur kereta tersebut dapat dilihat pada Gambar 1.

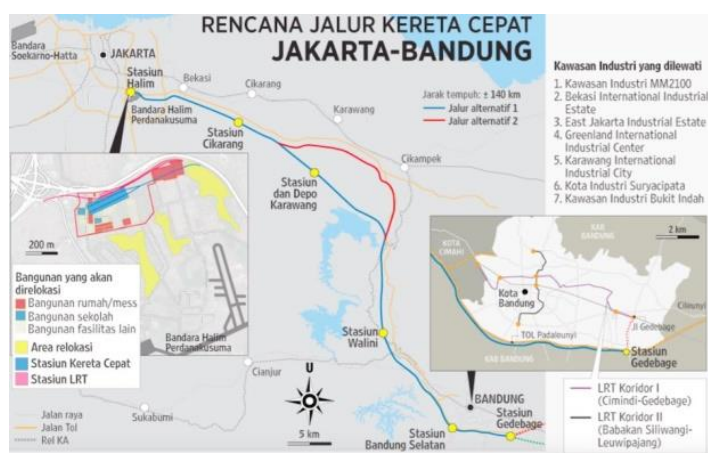

Gambar 1. Rencana Rute Kereta Cepat Jakarta - Bandung

Penelitian yang dilakukan meliputi seberapa besar daya dukung tanah awal dalam mendukung beban yang diakibatkan oleh beban gandar kereta cepat meliputi beban statis, siklik dan gempa.

Dengan melakukan penelitian diharapkan dapat mengetahui sifat sifat teknis-mekanis tanah timbunan sebagai tanah dasar (subgrade) untuk rel kereta cepat, mengetahui pengaruh campuran semen dan zat aditif terhadap stabilisasi tanah dasar terhadap sifat teknis dan mekanis tanah berupa parameter kepadatan tanah yaitu CBR (California Bearing Ratio) terendam dan UCS (Unconfined Compression Strength) dan melakukan simulasi numeris 2D terhadap pengaruh stabilisasi tanah dasar pada jalan rel kereta cepat.

Tujuan penelitian ini selain untuk mengetahui daya dukung tanah dasar juga untuk mendapatkan batasan daya dukung minimal yang telah ditetapkan oleh peraturan subgrade kereta cepat.. Oleh karena itu dilakukan penelitian terhadap perkuatan tanah dasar dimana parameter yang diuji meliputi:

1. Pengujian dilakukan pada kadar variasi penggunaan semen dan semen ditambah aditif (DIFA SS) untuk tanah $0,15 \% / \mathrm{m}^{3}$ tanah kering, dengan penggunaan kadar semen $1 \%, 2 \%$ dan $3 \%$ dari berat kering tanah. Penggunaan campuran tanah dan semen dapat meningkatkan daya dukung tanah dan mudah didapat, dan penggunaan DIFA SS sebagai bahan aditif perkuatan dapat menghemat penggunaan semen berlebih dalam peningkatan daya dukung tanah.

2. Parameter yang digunakan adalah nilai CBR (California Bearing Ratio) terendam dan nilai UCS (Unconfined Compression Strength) dengan lama pemeraman 1 hari, 7 hari dan 14 hari.

3. Simulasi numeris 2D dengan menggunakan Software Plaxis versi 8.6., dimana daya dukung tanah yang ditinjau dari besarnya penurunan tanah akibat beban kereta.

Penelitian stabilisasi tanah ex cikalong wetan untuk subgrade selama ini belum ada yang terpublikasi apalagi stabilisasi tanah tersebut dengan bahan semen dan aditif DIFA SS. Jadi penelitian ini belum bisa membandingkan dengan penelitian sebelumnya. Penelitian perkuatan tanah dengan semen dan DIFA SS sudah pernah dilakukan tetapi dengan jenis tanah yang berbeda dan juga lokasi penelitian yang berbeda sehingga tidak bisa dilakukan perbandingan penelitian.

\section{- Informasi Umum Jalan Rel Kereta Cepat}

Biasanya komponen kereta dapat didefinisikan dalam 2 (dua) kategori yaitu kategori super struktur yang terdiri dari rel, yaitu letak roda kereta untuk berjalan, slepeers yang berfungsi untuk mendistribusikan beban dari rel ke sub struktur dan juga sistem pengikat untuk menjaga rel berada tetap pada posisinya. Kategori kedua yaitu Sub struktur yang terdiri dari ballast, sub ballast dan subgrade (dapat dilihat pada Gambar 2 dan gambar 3). 


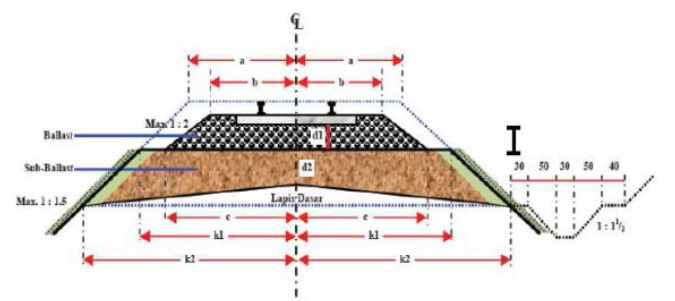

Gambar 2. Potongan melintang rel kereta (PM No. 60 Tahun 2012)

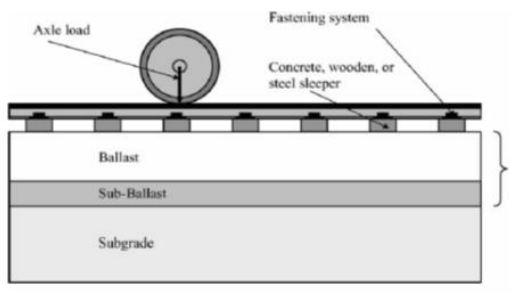

Gambar 3. Komponen dari rel kereta (Burrow, Bowness, and Ghataora, 2007).

\section{- Metode Internasional Perencanaan Jalan Kereta Cepat}

Secara empiris direkomendasikan suatu system desain dan perawatan pada sub struktur jalan kereta (Alamaa, 2016). Dimana rekomendasi tersebut bahwa sub struktur harus terdiri dari sebagian dan semua dari setiap lapisan yaitu ballast dan kerikil pada sub ballast, dan itu merupakan satu kesatuan dari lapisan trackbed.

Menurut The International Union Of Railway Methode (Alamaa, 2016), Tanah dasar dapat diklasifikasikan menjadi 4 (empat) bagian. Klasifikasi dari kualitas tanah dapat dilihat pada Tabel 1, dimana klasifikasi sub soil didasarkan pada kondisi tanah. Ada 4 (empat) klasifikasi tanah yaitu:

a. QS 0: yaitu terdiri dari tanah dengan kondisi lunak atau buruk dan diperlukan perbaikan pada tanah tersebut dengan modulus deformasi $\leq 20$ MPA

b. QS 1: yaitu tanah yang agak lunak tetapi harus juga dipertimbangkan perbaikan tanahnya.

c. QS 2: yaitu tanah dengan kualitas rata rata

d. QS 3: yaitu tanah dengan kualitas baik
Tabel 1. Daya dukung tergantung pada kualitas tanah pada embankment. (California High Speed Rail Authority, 2009)

Timbunan atau

Permukaan galian

\section{Klasif}

ikasi

tanah

QS1 2-3

CBR

ubgrade

Persyaratan

Subgrade

Ketebalan

Minimum

Subgrade (m)

QS2 $\quad 5 \quad$ P3

QS3 $\quad 10-17^{\mathrm{c}} \quad \mathrm{P} 3$

P3

P1

$\mathrm{P} 2$

$\mathrm{P} 3$

QS2

QS3

QS3

a. CBR dalam keadaan jenuh dilokasi

b. CBR terendam yang sesuai desain

c. Nilai yang diusulkan ERRI D117/RP (1983)

\section{- Beban Vertikal}

Beban vertikal statis merupakan beban primer pada kereta yang digunakan pada perancangan jalan kereta yang diakibatkan oleh beban pada roda yang juga pengaruh kecepatan pada kereta. Penambahan beban statis akibat beban dinamis sangat berpengaruh diakibatkan oleh efek dari geometry, rel atau roda, penambahan kecepatan dan factor kekakuan. Berdasarkan UIC (Union Internationale de Chemins de fer), batas dari beban vertikal akibat dari beban dinamis harus $\leq 17$ ton. Beban dinamis yaitu beban yang diakibatkan oleh beban siklik dari gandar kereta akibat dari pengaruh getaran pada saat kereta dengan frekuensi gelombang amplitudo tinggi pada kisaran $180-1200 \mathrm{~Hz}$ (Steenbergen, Jong dan Zoeteman, 2015), juga pengaruh beban gempa dimana besaran beban gempa untuk daerah Jawa Barat sebesar 0,3 $0,4 \mathrm{~g}$.

\section{- Sifat - sifat fisik dan mekanis tanah}

Untuk mengetahui sifat sifat fisik dan mekanik tanah biasanya dilakukan terlebih dahulu penelitian laboratorium terhadap tanah tersebut. Dan untuk mengetahui hal tersebut perlu dilakukan pengujian terhadap tanah tersebut. Dari hasil pengujian biasanya didapatkan nilai nilai fisik tanah berupa nilai kepadatan tanah, berat volume $(\gamma)$, kadar air $(w)$, nilai plastisitas tanah, persentase saringan dan juga parameter lainnya. Dan dari hasil 
pengujian mekanis tanah biasanya didapat nilai nilai mekanis tanah berupa nilai $\mathrm{CBR}, q u$, nilai cohesi (c), sudut gesek tanah $(\varphi)$, dan parameter mekanis tanah lainnya.

Hubungan korelasi antara nilai CBR dan modulus elastisitas adalah $E=16,2 \mathrm{CBR}^{0,7}$ $(\mathrm{MPa})$ untuk nilai $\mathrm{CBR}<5 \%$, untuk nilai $\mathrm{CBR}$ $>5 \%$ nilai $\mathrm{E}=22,4 \mathrm{CBR}^{0,5}(\mathrm{MPa})$, (Naasra,1950)

\section{- Kapasitas Dukung Tanah}

Bila tanah mengalami pembebanan seperti beban pondasi, tanah akan mengalami distorsi dan penurunan. Jika beban ini berangsur ditambah maka akan bertambah pula penurunannya (Hardiyatmo,2010). Kapasitas dukung ultimit (ultimate bearing capacity), (qu) didefinisikan sebagai beban maksimum persatuan luas dimana tanah masih dapat mendukung beban dengan tanpa mengalami keruntuhan. Bila dinyatakan dalam persamaan:

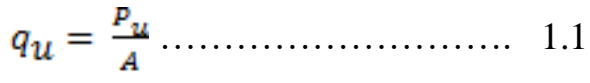

Dimana:

$q_{u}=$ kapasitas dukung ultimit $\left(\mathrm{kN} / \mathrm{m}^{2}\right)$

$P_{u}=$ Beban ultimit $(\mathrm{kN})$

$A=$ Luas beban $\left(\mathrm{m}^{2}\right)$

\section{- Stabilisasi dangkal}

Stabilisasi dangkal merupakan teknik stabilisasi yang sering diterapkan pada bidang jalan terutama untuk mengubah sifat-sifat dasar tanah (subgrade), atau lapis pondasi bawah (subbase) agar dapat memenuhi standar persyaratan teknik.

Pendekatan desain stabilisasi dangkal dengan memperhitungkan terlebih dahulu besarnya daya dukung tanah dengan persamaan 1.2.

$Q_{u}=c N_{c}+\gamma D N_{q}+0,5 B N_{\gamma} \ldots \ldots \ldots$

Dimana :

$Q_{u}=$ daya dukung tanah $\left(\mathrm{kN} / \mathrm{m}^{2}\right)$

$c=$ cohesi $\left(\mathrm{kN} / \mathrm{m}^{2}\right)$

$\gamma=$ berat volume tanah $\left(\mathrm{kN} / \mathrm{m}^{3}\right)$

$D=$ kedalaman tanah yang ditinjau $(\mathrm{m})$

$B=$ lebar pondasi atau timbunan $(\mathrm{m})$

$N_{c}, N_{q}, N_{\gamma}=$ factor daya dukung (dalam grafik dan tabel yang dikembangkan oleh Terzaghi 1943.

\section{METODE PENELITIAN}

\section{Lokasi Penelitian}

Lokasi penelitian terletak pada desa Walini, Cikalong Wetan Kabupaten Bandung Barat (Lihat Gambar 4)
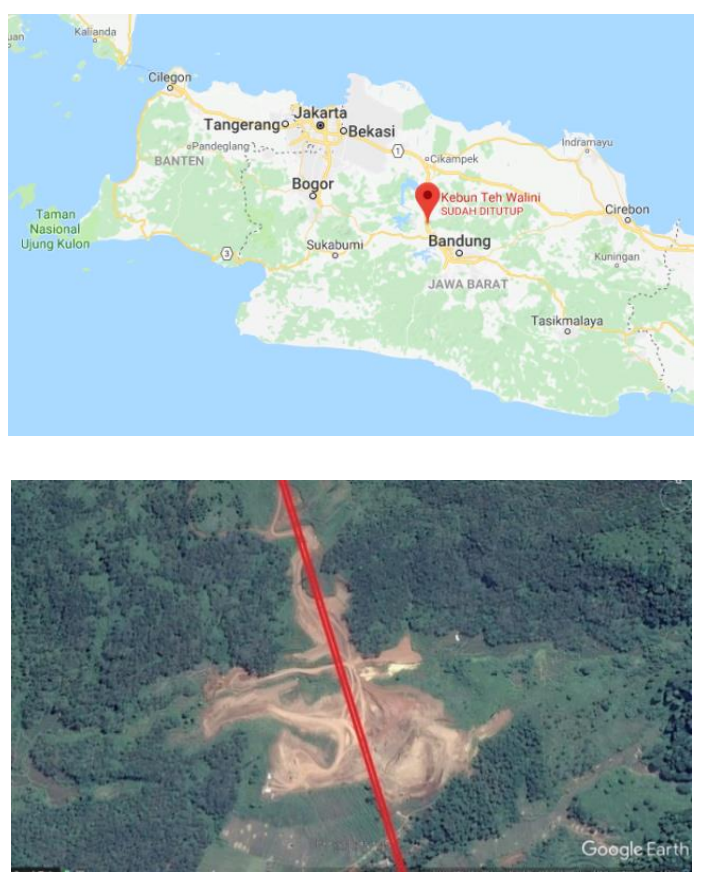

Gambar 4. Lokasi Penelitian

\section{Bahan Penelitian}

a. Tanah

Material tanah adalah material yang diambil di Desa Cikadal, Cikalong Wetan Kabupaten Bandung Barat.

b. Bahan Aditif

Bahan aditif yang merupakan serbuk anorganik yang bekerja sebagai ion exchange dimana prinsip kerjanya adalah menyisihkan materi yang berada pada permukaan tanah dan berfungsi mensatbilkan serta memadatkan tanah. Bahan aditif yang digunakan adalah DIFA SS.

c. Semen

Semen tipe portland (Dipakai semen merk "Tiga Roda").

d. Air

Air yang digunakan diambil dari saluran air bersih di laboratorium Mekanika Tanah Departemen Teknik Sipil Universitas Gadjah Mada Yogyakarta. 


\section{Variasi Pengujian}

Target nilai CBR yang ingin dicapai dalam peneletian ini sesuai dengan yang diusulkan ERRI D117/RP (1983) yaitu dengan nilai CBR sebesar $10 \%$ sesuai dengan persyaratan minimal yang diusulkan. Sedang dalam pengujian awal didapat nilai CBR terendam sebesar $8,17 \%$ mendekati nilai persyaratan subgrade minimal. Maka prosentase campuran semen dan zat aditif diambil pada kisaran $1-3 \%$ dan zat aditif sebesar $0,15 \%$ MDD. Jumlah sampel pengujian masing masing campuran dan lama pemeraman sebanyak 2 sampel untuk pengujian CBR terendam dan 2 sampel untuk pengujian UCS.

Variasi pengujian campuran semen dan zat aditif dapat dilihat pada tabel 2

Tabel 2. Variasi Pengujian

\begin{tabular}{clcc}
\hline No. & Variasi Pengujian & $\begin{array}{c}\text { Kadar } \\
\text { Semen }\end{array}$ & $\begin{array}{c}\text { Zat } \\
\text { Aditif }\end{array}$ \\
\hline \multirow{2}{*}{1} & Tanah + Semen & $\begin{array}{c}1 \%, 2 \% \\
\text { dan 3\% }\end{array}$ & - \\
& Tanah + Semen + Zat & $\begin{array}{c}1 \%, 2 \% \\
\text { 2an 3\% }\end{array}$ & $\begin{array}{c}0.15 \% \\
\text { (MDD) }\end{array}$ \\
\cline { 2 - 3 } & Aditif & dan & \\
\hline
\end{tabular}

\section{HASIL DAN PEMBAHASAN}

Karakteristik Tanah Awal

Dari hasil pengujian laboratorium yang dilakukan didapat jenis tanah yang berupa tanah lanau dengan plastisitas sangat rendah. Hubungan Kadar Air dan Berat Kering Tanah didapat prosentasi kadar air (OMC) sebesar $30.5 \%$ yang akan dijadikan prosentase campuran kadar air yang akan dijadikan prosentase kadar air untuk tahap pengujian selanjutnya dengan Nilai Padat Kering Optimum (MDD) $1.31 \mathrm{gr} / \mathrm{cm}^{3}$. Hubungan kadar air dan berat kering tanah dapat dilihat pada Gambar 5.

Nilai CBR tak terendam dan CBR terendam tanah asli dapat dilihat Tabel 3.

Tabel 3. Hasil Pengujian Nilai CBR

\begin{tabular}{lcc}
\hline \multicolumn{1}{c}{ Parameter } & Satuan & Nilai \\
\hline CBR Tak Terendam $($ Unsoaked $)$ & $\%$ & 15.09 \\
CBR Terendam $($ Soaked $)$ & $\%$ & 8.17 \\
\hline
\end{tabular}

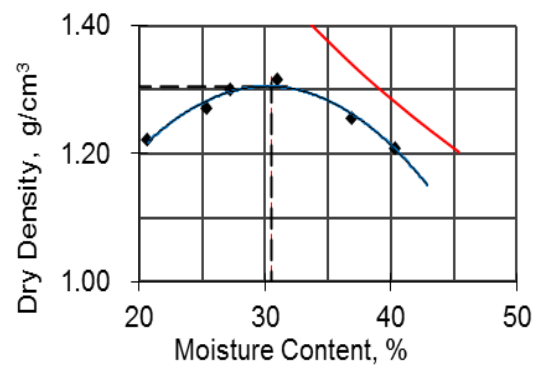

Maximum Dry Density (MDD) : $1.31 \mathrm{gr} / \mathrm{cm}^{3}$

Optimum Moisture Content (OMC) : $30.5 \%$

Gambar 5. Gambar Hubungan Kadar Air dan Berat Kering Tanah

Berdasar hasil uji proctor dan nilai CBR dan didukung oleh pengujian sifat fisik tanah berdasar data sekunder, tanah asli termasuk dalam kelompok tanah lanau dengan plastisitas rendah atau ML berdasar klasifikasi Unified (Rolling dan Rolling, 1996) dan berdasar klasifikasi AASHTO tanah mempunyai klasifikasi A5 (Gregg, 1960).

Dari hasil pengujian CBR awal terendam didapat bahwa nilai CBR tanah awal sebesar $8,17 \%$, sesuai dengan Tabel 1.1 Daya dukung tergantung pada kualitas tanah pada embankment. (California High Speed Rail Authority, 2009), tanah termasuk dalam kualitas QS 2, dalam ERRI D117/RP (1983) karena nilai CBR kurang dari persyaratan minimal yaitu 10\%, maka diperlukan perkuatan stabilisasi tanah dengan penambahan semen dan zat aditif.

\section{Pengaruh Penambahan Semen dan Zat Aditif \\ Hasil Pengujian California Bearing Ratio (CBR)}

- Hasil Pengujian Campuran Tanah dan Variasi Semen

Hasil pengujian CBR terendam pada pemeraman 1 (satu) hari dengan kadar semen $1 \%, 2 \%$ dan $3 \%$ didapat nilai CBR yang meningkat dari CBR awal (tidak bercampur) yang terendam, dimana nilai CBR masing masing campuran $19,33 \%, 26,41 \%$ dan $31,33 \%$. Untuk pemeraman 7 (tujuh) hari dengan campuran yang sama kemudian direndam, didapat nilai CBR untuk masing masing campuran $42,76 \%, 50,98 \%$ dan 58,16 $\%$. Dan untuk pemeraman selama 14 (empat belas) hari nilai $\mathrm{CBR}$ untuk masing masing 
campuran adalah 51,61\%, 60,26\% dan 71,21 $\%$. Hasil dari pengujian CBR terendam campuran antara tanah, dan variasi semen dapat dilihat pada Tabel 4 dan Gambar 6.

Tabel 4. Nilai CBR terendam (soaked) dengan lama pemeraman dengan variasi semen

\begin{tabular}{ccccc}
\hline Variasi & \multicolumn{4}{c}{ Lama Pemeraman } \\
Semen & 0 hari & 1 hari & 7 hari & 14 hari \\
\hline $0 \%$ & 0.00 & - & - & - \\
$1 \%$ & - & 19.33 & 42.76 & 51.61 \\
$2 \%$ & - & 26.41 & 50.98 & 60.26 \\
$3 \%$ & - & 31.33 & 58.16 & 71.21 \\
\hline
\end{tabular}

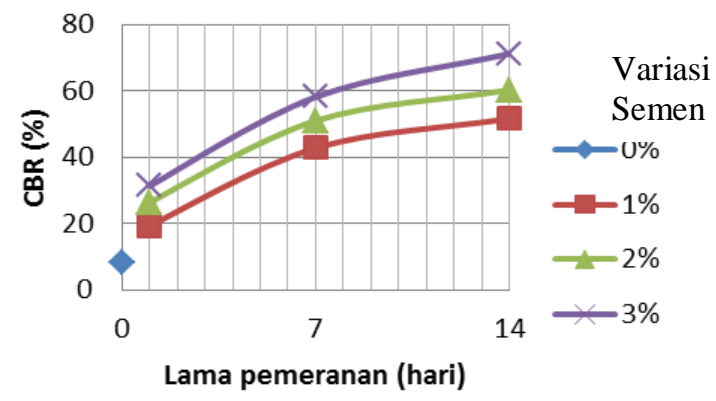

Gambar 6. Nilai CBR terendam (soaked) dengan lama pemeraman dengan variasi semen

- Hasil Pengujian Campuran Tanah, Aditif dan Variasi Semen

Hasil pengujian tanah dicampur dengan variasi semen dan zat aditif sebanyak $0,15 \%$ dari berat kering tanah. Hasil uji CBR tersebut setelah diperam selama 1 (satu) hari, 7 (tujuh) hari dan 14 (empat belas) hari, kemudian direndam didalam air selama 4 (empat) hari. nilai CBR terendam pada pemeraman 1 (satu) hari dengan kadar semen $1 \%, 2 \%$ dan $3 \%$ didapat nilai CBR masing masing campuran $23,26 \%, 36,31 \%$ dan 44,64\%. Untuk pemeraman 7 (tujuh) hari dengan campuran yang sama kemudian direndam, didapat nilai CBR untuk masing masing campuran 58,79\%, $76,29 \%$ dan $95,47 \%$. Dan untuk pemeraman selama 14 (empat belas) hari nilai CBR untuk masing masing campuran adalah 67,85 \%, $87,50 \%$ dan $106,42 \%$. Hasil dari pengujian CBR terendam campuran antara tanah, zat aditif dan variasi semen dapat dilihat pada Tabel 5 dan Gambar 7.
Tabel 5. Nilai CBR terendam (soaked) dengan lama pemeraman dengan zat aditif dan variasi semen

\begin{tabular}{ccccc}
\hline Variasi & \multicolumn{4}{c}{ Lama Pemeraman } \\
Semen & 0 hari & 1 hari & 7 hari & 14 hari \\
\hline $0 \%$ & 8.17 & - & - & - \\
$1 \%$ & - & 23.26 & 58.79 & 67.85 \\
$2 \%$ & - & 36.31 & 76.29 & 87.50 \\
$3 \%$ & - & 44.64 & 95.47 & 106.42 \\
\hline
\end{tabular}

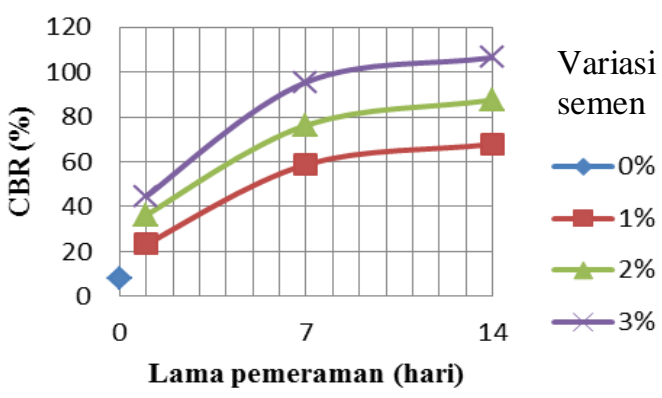

Gambar 7. Nilai CBR terendam (soaked) dengan lama pemeraman dengan zat aditif dan variasi semen

\section{Hasil Pengujian Unconfined Compression Strength (UCS)}

- Hasil Pengujian Campuran Tanah dan Variasi Semen

Pada Tabel 6 dan Gambar 7 campuran antara semen dan tanah didapat nilai UCS (qu) pada campuran semen 1\%, 2\% dan 3\% dengan lama pemeraman 1 (satu) hari. Nilai qu untuk masing masing campuran yaitu $1,47 \mathrm{~kg} / \mathrm{cm}^{2}$, $1,69 \mathrm{~kg} / \mathrm{cm}^{2}$, dan $1,93 \mathrm{~kg} / \mathrm{cm}^{2}$. Sedang untuk lama pemeraman selama 7 (tujuh) hari didapat nilai $q u$ sebesar $1,84 \mathrm{~kg} / \mathrm{cm}^{2}, 2,11 \mathrm{~kg} / \mathrm{cm}^{2}$, dan $2,29 \mathrm{~kg} / \mathrm{cm}^{2}$. Untuk lama pemeraman selama 14 (empat belas) hari didapat nilai $q u$ sebesar $2,07 \mathrm{~kg} / \mathrm{cm}^{2}, 2,39 \mathrm{~kg} / \mathrm{cm}^{2}$, dan $2,57 \mathrm{~kg} / \mathrm{cm}^{2}$. Terjadi peningkatan nilai $q u$ dari masing masing nilai campuran semen dan lamanya pemeraman.

Tabel 6. Nilai $q u$ dari hasil uji UCS campuran variasi semen

\begin{tabular}{cccc}
\hline Variasi & \multicolumn{3}{c}{ Lama Pemeraman } \\
Semen & 1 hari & 7 hari & 14 hari \\
\hline $1 \%$ & 1.47 & 1.84 & 2.07 \\
$2 \%$ & 1.69 & 2.11 & 2.39 \\
$3 \%$ & 1.93 & 2.29 & 2.57 \\
\hline
\end{tabular}




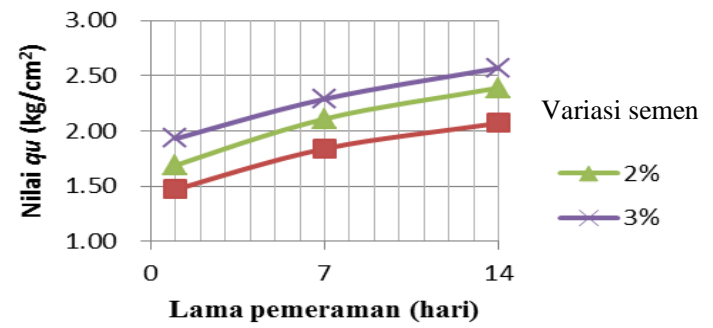

Gambar 8. Nilai $q u$ dari hasil uji UCS campuran variasi semen

- Hasil Pengujian Campuran Tanah, Aditif dan Variasi Semen

Pada Tabel 7 dan Gambar 9 campuran antara semen, tanah dan zat aditif didapat nilai UCS ( $q u$ ) pada campuran semen 1\%, $2 \%$ dan $3 \%$ dengan lama pemeraman 1 (satu) hari, nilai $q u$ untuk masing masing campuran yaitu $1,49 \mathrm{~kg} / \mathrm{cm}^{2}, 1,89 \mathrm{~kg} / \mathrm{cm}^{2}$, dan $2,05 \mathrm{~kg} / \mathrm{cm}^{2}$. Sedang untuk lama pemeraman selama 7 (tujuh) hari didapat nilai $q u$ sebesar 2,12 $\mathrm{kg} / \mathrm{cm}^{2}, 2,46 \mathrm{~kg} / \mathrm{cm}^{2}$, dan $2,85 \mathrm{~kg} / \mathrm{cm}^{2}$. Untuk lama pemeraman selama 14 (empat belas) hari didapat nilai qu sebesar $2,44 \mathrm{~kg} / \mathrm{cm}^{2}, 2,83$ $\mathrm{kg} / \mathrm{cm}^{2}$, dan $3,11 \mathrm{~kg} / \mathrm{cm}^{2}$. Terjadi peningkatan nilai qu dari masing- masing nilai campuran semen dan lamanya pemeraman. Pengaruh campuran semen dan tanah dibandingkan dengan campuran semen, zat aditif dan tanah terdapat kenaikan nilai $q u$, tetapi kenaikan tersebut tidak signifikan. Lama pemeraman pula tidak begitu mempengaruhi nilai $q u$ pengikatan antara tanah, semen, air dan zat aditif terjadi tetapi tidak cukup untuk menjadikan nilai $q u$ tersebut mendekati nilai pengujian CBR. Jika dilakukan perendaman terhadap benda uji maka benda uji tersebut akan hancur. Sehingga pengujian UCS hanya dilakukan pada benda uji yang tidak terendam.

Tabel 7. Nilai $q u$ dari hasil uji UCS campuran aditif dan variasi semen

\begin{tabular}{cccc}
\hline Variasi & \multicolumn{3}{c}{ Lama Pemeraman } \\
Semen & 1 hari & 7 hari & 14 hari \\
\hline $1 \%$ & 1.49 & 2.12 & 2.44 \\
$2 \%$ & 1.89 & 2.46 & 2.83 \\
$3 \%$ & 2.05 & 2.85 & 3.11 \\
\hline
\end{tabular}

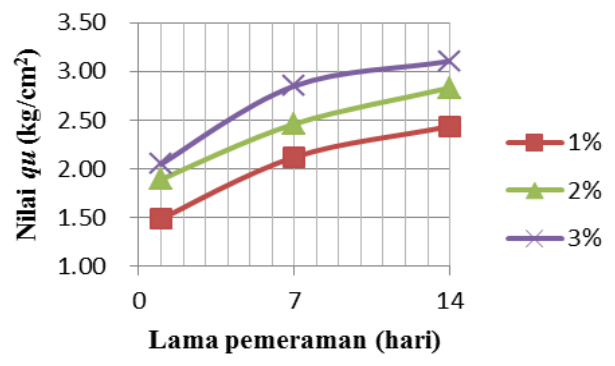

Gambar 9. Nilai $q u$ dari hasil uji UCS campuran aditif dan variasi semen

Perbandingan besaran nilai CBR terendam, lama pemeraman, variasi semen dan zat aditif dapat dilihat pada Gambar 10. Terlihat besaran peningkatan nilai CBR terendam dari tanah asli ke campuran variasi semen. Peningkatan lebih besar lagi terjadi ketika tanah asli dicampur dengan zat aditif dan variasi semen. Pada pemeraman 1 hari perbedaan nilai CBR tidak terlalu besar hal ini mungkin disebabkan oleh belum mengikatnya zat aditif dan variasi semen. Perbedaan nilai CBR yang sangat besar pada antara tanah, dan variasi semen dengan tanah, zat aditif, dan variasi semen terjadi pada saat pemeraman yang terjadi pada 7 hari dan pada 14 hari.

Perbandingan besaran nilai $q u$ untuk campuran tanah dan variasi semen dibanding campuran tanah, zat aditif dan variasi semen dapat dilihat pada Gambar 11. Pada besaran nilai UCS nilai $q u$ pada saat campuran $1 \%$ semen saja dan juga ditambah zat aditif terjadi peningkatan nilai qu yang tidak begitu besar baik itu pada pemeraman 1 hari, 7 hari dan 14 hari, tetapi ketika nilai campuran, baru setelah variasi campuran semen mencapai $2 \%$ dan $3 \%$ terjadi selisih perbandingan yang cukup jauh untuk nilai $q u$. 


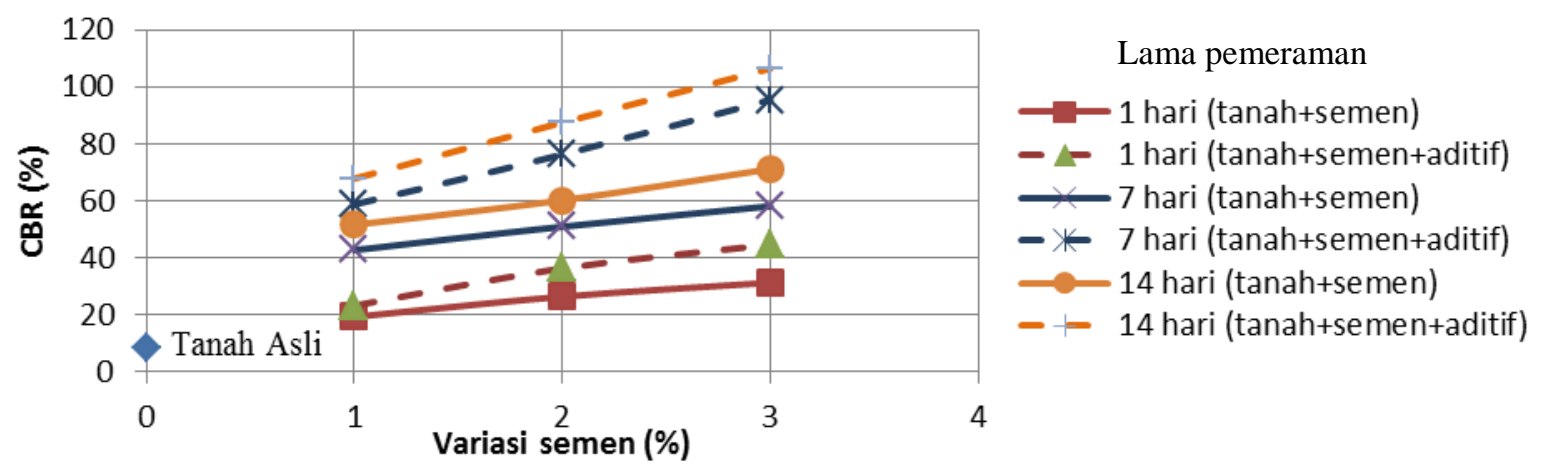

Gambar 10. Perbandingan nilai CBR terendam antara tanah asli, campuran variasi semen dan zat aditif ditambah variasi semen

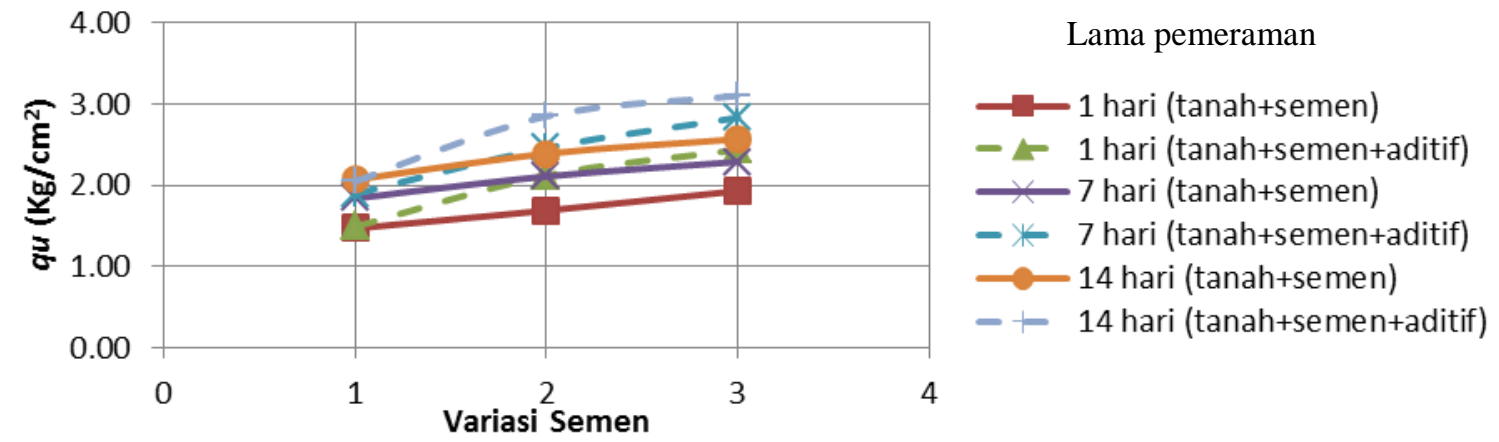

Gambar 11. Perbandingan nilai UCS antara tanah asli, campuran variasi semen dan zat aditif ditambah variasi semen

- Analisis Stabilitas Daya dukung Tanah Menggunakan Plaxis 8.6

\begin{tabular}{lcc}
\hline Lapisan Tanah & Satuan & Tebal \\
\hline Tanah Urug (Tanah awal) & $\mathrm{m}$ & 5.5 \\
Subgrade (Tanah + Aditif + & $\mathrm{m}$ & 0.35 \\
Semen 1\%) & & \\
Ballast (kerikil) & $\mathrm{m}$ & 0.3 \\
\hline
\end{tabular}

Dari data data hasil penelitian didapatkan, kemudian dilakukan analisis daya dukung tanah dengan menggunakan analisis PLAXIS 8.6, adapun perancangan tebal dari tanah timbunan, subgrade dan ballast dapat dilihat pada Tabel 8 dan gambar dari embankment kereta cepat dapat dilihat pada gambar 12 dan gambar 13.
Tabel 8. Tebal masing masing timbunan

\begin{tabular}{|c|c|c|}
\hline Lapisan Tanah & Satuan & Tebal \\
\hline Tanah Urug (Tanah awal) & $\mathrm{m}$ & 5.5 \\
\hline $\begin{array}{l}\text { Subgrade (Tanah + Aditif + } \\
\text { Semen } 1 \%)\end{array}$ & $\mathrm{m}$ & 0.35 \\
\hline Ballast (kerikil) & $\mathrm{m}$ & 0.3 \\
\hline 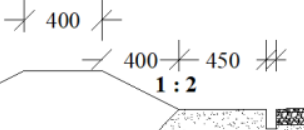 & $\begin{array}{l}500 \\
\text { Ballast } \\
\text { Bast }\end{array}$ & $50+_{4}$ \\
\hline
\end{tabular}

Gambar 12. Gambar rancangan timbunan 


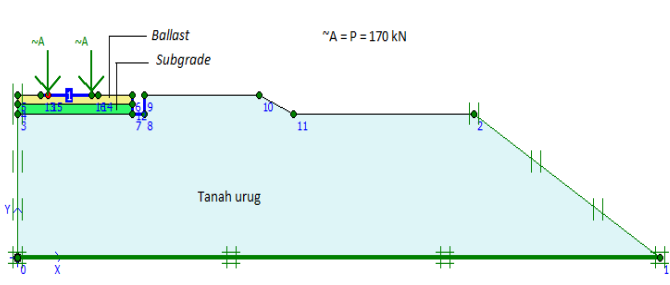

Gambar 13. Gambar rancangan subgrade dan ballast

Dari hasil perhitungan plaxis 8.6 penurunan yang terjadi akibat beban statis sebesar -0,065 $\mathrm{mm}$ lebih kecil dari penurunan ijin yang disyaratkan pada pondasi dangkal yaitu $4 \mathrm{~cm}$ (Skempton dan Mac Donald, 1955), lihat Gambar 14. Penurunan pondasi akibat beban dinamis yaitu beban siklik $0,015 \times 10^{-3} \mathrm{~mm}$, itu berarti untuk penurunan tanah sedalam $4 \mathrm{~cm}$ atau $40 \mathrm{~mm}$ diperlukan 2.666.667 kali beban siklik yang melewati lintasan kereta tersebut. Artinya subgrade mampu menahan beban gandar kereta sebesar $170 \mathrm{kN}$ dengan frekuensi axle load untuk frekuensi tinggi sebesar $1.200 \mathrm{hz}$ (Steenbergen, Jong dan Zoeteman, 2015), lihat Gambar 15. Penurunan pondasi akibat beban siklik dan gempa sebesar $0,4 \mathrm{~g}$ untuk wilayah Jawa Barat sebesar 0,576 x $10^{-3} \mathrm{~mm}$, lihat gambar 16. Analisis penurunan tanah dilakukan pada bagian tengah subgrade diantara kedua beban gandar kereta.

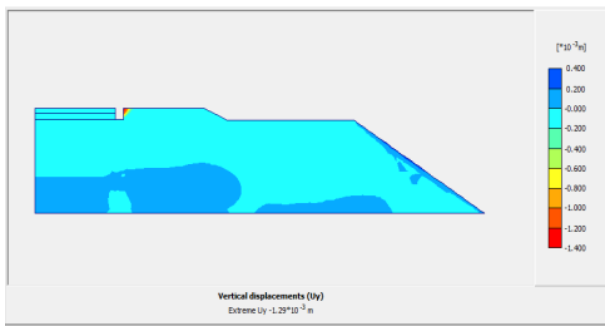

Gambar 14. Hasil perhitungan daya dukung tanah akibat beban statis

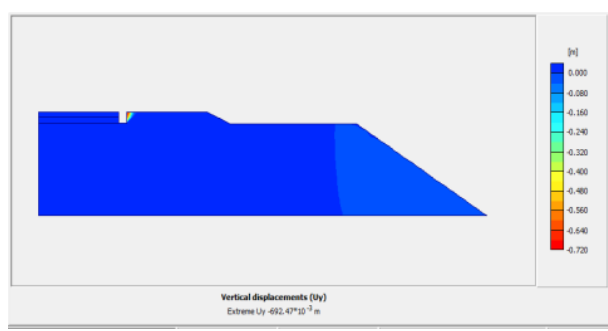

Gambar 15. Hasil perhitungan daya dukung tanah akibat beban dinamis/siklik

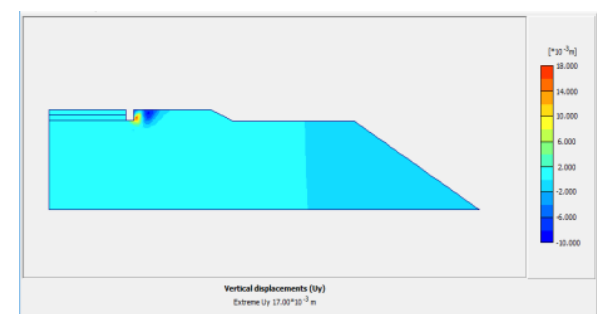

Gambar 16. Hasil perhitungan daya dukung tanah akibat beban siklik dan beban gempa

Dari hasil perhitungan daya dukung tanah, ketebalan subgrade dan ballast juga modulus elastisitas keduanya sangat berpengaruh pada daya dukung tanah dalam menahan beban diatasnya. Semakin tinggi nilai CBR yang digunakan, dan ketebalan subgrade maka akan semakin meningkatnya daya dukung tanah.

\section{KESIMPULAN DAN SARAN}

\section{Kesimpulan}

Dari Hasil Analisis Laboratorium dan Analisis Plaxis didapat kesimpulan sebagai berikut :

a. Hasil uji terhadap tanah yang diambil dari Desa Cikadal, Cikalong Kabupaten Bandung Barat merupakan tanah lanau dengan plastisitas rendah. Hasil uji laboratorium CBR (California Bearing Ratio)dari tanah awal didapat nilai CBR terendam sebesar $8.17 \%$, dimana tanah tersebut dapat digunakan untuk tanah timbunan pada proyek kereta cepat, dimana CBR minimal berdasarkan peraturan adalah 6\%. Nilai CBR terendam sebesar $8.17 \%$, tanah tersebut tidak dapat digunakan untuk subgrade kereta cepat, karena berdasarkan rekomendasi ERRI Report D117/RP 28 (1983) batasan persyaratan minimal nilai CBR untuk subgrade sebesar 10. Maka diperlukan campuran semen dan bahan aditif untuk meningkatkan nilai CBR.

b. Dari hasil pengujian laboratorium untuk variasi campuran antara pasir dan semen dengan penggunaan variasi semen $1 \%$ dari berat kering tanah, dengan lama pemeraman 14 hari didapat nilai CBR terendam sebesar $51.61 \%$, dan untuk campuran semen $1 \%$ dan zat aditif didapat nilai CBR terendam sebesar $67.85 \%$. Terjadi peningkatan yang cukup signifikan dari kedua perbandingan campuran tersebut. Dari 
hasil kedua campuran tersebut dapat digunakan untuk subgrade kereta cepat.

c. Dari hasil Analisis numeris Plaxis 8.6, dengan ketebalan subgrade $0,35 \mathrm{~m}$, nilai deformasi terhadap pengaruh beban gandar terjadi penurunan akibat beban statis sebesar $-0,065 \mathrm{~mm}$ dan penurunan akibat beban dinamis gandar kereta sebesar $0,015 \times 10^{-3} \mathrm{~mm}$, itu berarti untuk penurunan tanah sedalam $4 \mathrm{~cm}$ atau $40 \mathrm{~mm}$ diperlukan $2.666 .667 \mathrm{kali}$ beban siklik yang melewati lintasan kereta tersebut, untuk beban siklik dan beban gempa sebesar $0,4 \mathrm{~g}$ penurunan yang terjadi sebesar $0,576 \times 10^{-3} \mathrm{~mm}$. Campuran tanah, semen $1 \%$ dan zat aditif 1,5 MDD tersebut subgrade dengan ketebalan $35 \mathrm{~cm}$ mampu menahan beban gandar dari kereta cepat.

\section{Saran}

Saran yang dapat diberikan dalam hasil penelitian ini sebagai berikut :

a. Pada penelitian tersebut tanah yang digunakan untuk subgrade dengan campuran yang teah dilaksanakan ternyata menghasilkan nilai CBR yang cukup besar. Perlu dilakukan penelitian penggunaan campuran tanah, semen dan zat aditif diperkecil hingga dibawah $1 \%$ untuk campuran semen, dan penggunaan zat aditif yang juga diperkecil untuk mendapatkan nilai CBR terendam yang effektif

b. Pada penelitian ini lama pemeraman hanya sampai 14 (empat belas) hari, dari beberapa penelitian masih terlihat penigkatan nilai CBR, dan UCS, ada yang bersifat linier dan belum diketahui titik konstan nilai nilai tersebut. Lama pemeraman dapat dilakukan hingga 21 (dua puluh satu) dan 28 (dua puluh delapan) hari.

\section{DAFTAR PUSTAKA}

Alamaa A. (2016). High Speed Railway Embankment - a Comparison of Different Regulation. Department of Civil and Architure Engineering, Division of Rock and Soil Mechanic, KTH Royal Institue of Technology, Stockholm

Badan Standarisasi Nasional. (2012). Tata Cara Perencanaan Ketahanan Gempa Untuk Struktur Bangunan Gedung dan Non Gedung, Jakarta
Bowles JE. (1989). Sifat-sifat Fisik dan Geoteknis Tanah. Jakarta: Erlangga.

Fly California. (2009). Technical Memorandum, Earth Work and Track Bed Design Guidelines, California

Gregg, L.E. (1960). Earthwork in K.B.Woods (ed), Highway Engineering Handbook. New York : Mcgraw Hill Book Company.

Hardiyatmo,H.C. (2002). Teknik Pondasi 1. Yogyakarta: Gadjah Mada University Pers.

M.J.M.M. Steenbergen, E.De Jong and A. Zoeteman (2015). Dynamic Axle Loads as a Main Source of Railway Track Degradation, Railway Engineering Group. Netherland: Delft University of Technology.

Peraturan Menteri Perhubungan Republik Indonesia (2012). Persyaratan Teknis Jalur Kereta Api, Nomor PM 60, Jakarta.

Plaxis 2D Versi 8. (2007). Manual Plaxis, Netherland: Delft University of Technology.

Raymod, G.P., ang Komos, G.A. (1978) Repeated Load Testing of a Model Plane Strain Footing, Canadian Geotech.J. 